\title{
SHALAT DAN KHUTBAH JUMAT DI SINJAI (TELAAH FENOMENA NONGKRONG DI LUAR MESJID SAAT KHUTBAH)
}

\author{
Muh. Anis ${ }^{1^{*}}$, Kusnadi $^{2}$, Rahmatullah $^{3}$ \\ ${ }^{1}$ Institut Agama Islam Muhammadiyah Sinjai \\ Email: totangka077@gmail.com,Telepon:+6285299526057 \\ ${ }^{2}$ Institut Agama Islam Muhammadiyah Sinjai, Sinjai \\ Email: adhybugiez@gmail.com,Telepon:+628114178104 \\ ${ }^{3}$ Institut Agama Islam Muhammadiyah Sinjai \\ Email: rahmatullahiaim@gmail.com, Telepon: +6281268928954
}

\begin{abstract}
Abstrak
Penelitian ini, Pelaksanaan Shalat dan Khutbah Jumat di Sinjai (Telaah Fenomena Nongkrong di Luar Mesjid Saat Khutbah), maka ada dua frame work yang menjadi fokus penelitian, yakni: pertama, analisis konsepsi mengenai pelaksanaan shalat dan khutbah Jumat berdasarkan dalil-dalil al-Qur'an- Hadis, paradigma shalat dan khutbah Jumat perspektif mazhab fiqih ibadah. Kedua, fenomena kebiasaan nongkrong di luar mesjid saat khutbah berlangsung. Penelitian ini berusaha menemukan masalah yang menyebabkan fenomena tersebut muncul menjadi realitas yang cenderung mentradisi di seluruh mesjid tempat pelaksanaan shalat Jumat di Kabupaten Sinjai. Dalam penelitian ini dengan metode kualitatif pendekatan teori-teori sosiologi, antropologi, dan teologi. Selain itu, pada pembahasan penelitian ini akan disertai dengan rekomendasi-rekomendasi solusi pemecahan masalah atau langkah-langkah alternatif yang dapat ditempuh mengatasi masalah. Sehingga hasil penelitian ini mengemukakan bahwa, Shalat Jumat dan khutbah merupakan satu rangkaian yang tidak terpisahkan dalam prosesi ibadah di hari jumat. Eksistensi khutbah dalam prosesi shalat jumat sangat jelas ditinjau dari landasan dalil-dalil dan hikmah yang terkandung di dalamnya bagi kaum muslimin. Karenanya, pelaksanaan prosesi shalat dan khutbah jumat perlu ada manajemen dari pengurus/ta'mir mesjid. Untuk itu penting ada konsep tertulis mengenai perencanaan, pelaksanaan, dan evaluasi untuk pelaksanaan shalat dan khutbah jumat. Selain itu, mesjid sebagai pusat ibadah kaum muslimin sekaligus sebagai tempat berkumpul menghendaki adanya fasilitas yang memadai. Fasilitas yang memadai dalam mesjid akan membuat betah jama'ah. Masalah pengadaan fasilitas di setiap mesjid biasanya terkendala dengan kemampuan dana mesjid. Akan tetapi hal ini dapat diatasi dengan ikhtiar dari para pengurus mesjid kepada pihak-pihak donatur baik perseorangan maupun lembaga tertentu untuk pengadaan fasilitas. Satu hal yang perlu dicatat bahwa rata-rata berdirinya mesjid berdasarkan swadaya masyarakat itu sendiri.
\end{abstract}

Kata Kunci : Khutbah Jum'at, Sholat Jum'at, Nongkrong Di luar Mesjid. 


\section{Pendahuluan}

Penciptaan manusia dalam khazanah filsafat memunculkan pertanyaan mendalam. Pertanyaan tersebut sederhana, akan tetapi untuk menjawabnya, banyak paradigma yang muncul sebagai dasar. Perspektif jawabannya pun berbeda sumber referensi. Pertanyaan itu mengenai, darimana manusia itu diciptakan? Untuk apa ia diciptkan?, dan bagaimana-akan kemana dia setelah mati? Hanya dua paradigma yang menjadi dasar manusia untuk menjawab pertanyaan-pertanyaan tersebut. Pertama, paradigma teologis. Konsep paradigma ini memandang asal-penciptaan manusia dari-oleh Tuhan, diciptakan ke dunia untuk melaksanakan perintah dan menjauhi larangan-Nya, setelah manusia mati di dunia maka kehidupan akhirat yang abadi menunggunya. Kedua, paradigma rasional. Konsep rasional ini memandang manusia bahwa manusia ada dengan sendirinya di dunia ini. Teori evolusi Darwin secara spekulatif menyebutkan bahwa manusia merupakan hasil evolusi dari makhluk sejenis kera. Keberadaannya di dunia hanya bertujuan untuk bagaimana membuat dirinya senang dan bahagia, dan setelah mereka mati di dunia maka sampai di situ saja kehidupannya, setelah itu tidak ada lagi kehidupan.

Memahami kedua paradigma tersebut, dapat dikatakan bahwa implikasi hidup dalam paradigma teologis memiliki konsekuwensi yakni pertanggungjawaban hidup. Sedangkan dalam paradigma rasional, implikasi kehidupan di dunia tidak memiliki konskuwensi kecuali kehidupan manusia itu sendiri selama hidup. Perbedaan subtantif kedua paradigma tersebut berada pada sumber pengetahuan mengenai konsep hidup dan kehidupan itu sendiri. Dalam bahasa lain, paradigma teologis berdasarkan wahyu, sedangkan paradigma rasionalistis berdasarkan akal murni manusia. Karena itu, paradigma teologis bersifat qathi; pasti yang dogmatis-doktrinal dan paradigma rasionalis bersifat spekulatif dan sementara atas konklusi yang diambil.

Penciptaan manusia dalam ajaran Islam memiliki tujuan. Mengetahui dan memahami serta berusaha mencapai tujuan tersebut, bagi muslim hukumnya wajib. Mengapa? karena manusia yang lahir ke dunia ini sesungguhnya tidak pernah minta dilahirkan. Manusia hadir ke dunia ini karena dikehendaki. Ada dua 
subjek yang menghendaki kelahiran manusia, pertama: Allah swt, kedua: pasutri. Kehendak Allah bersifat mutlak sedangkan kehendak suami istri bersifat relatif. Disebut relatif karena keinginan suami istri untuk hamil dan melahirkan seorang bayi tidak pasti. Banyak kasus pasutri yang menginkan kehamilan setelah pernikahannya, namun setelah bertahun-tahun mereka belum memiliki keturunan. Padahal berdasarkan diagnosis medis, keduanya normal. Sehingga bagi pasutri yang telah menikah bertahun-tahun tetapi belum memiliki keturunan, disarankan agar memperbanyak istigfar dan doa.

Kembali pada tujuan penciptaan manusia, Allah swt berfirman dalam QS Adz Dzaariaat/51: 56,

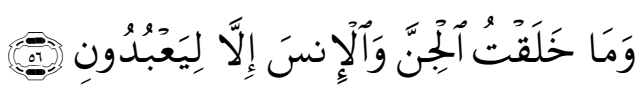

56. dan aku tidak menciptakan jin dan manusia melainkan supaya mereka mengabdi kepada-Ku.

Pada ayat ini, Allah swt menegaskan bahwa tujuan penciptaan manusia untuk beribadah/mengabdi kepada-Nya. Bahkan selain manusia, ada makhluk lain yang juga diciptakan bertujuan untuk mengabdi kepada-Nya yakni bangsa Jin. Kata liya'buduuni yang diterjemahkan "mengabdi", membawa dua makna ketundukan dan ketaatan pada aturan-Nya bagi manusia. Ketundukan dan ketaatan dituntut kepada manusia selama mereka hidup di dunia saja. Dua makna ini, jika direfleksikan dalam perspektif hukum maka ia berisi tentang perintah, larangan, janji, dan acaman kepada manusia selama hidup di dunia.

Salah satu bentuk perintah ibadah;mengabdi kepada Allah swt adalah shalat Jumat. Shalat Jumat dikerjakan pada hari jumat secara berjamaah. Hal ini ditegaskan oleh Allah dalam QS al Jumu'ah/62:9,

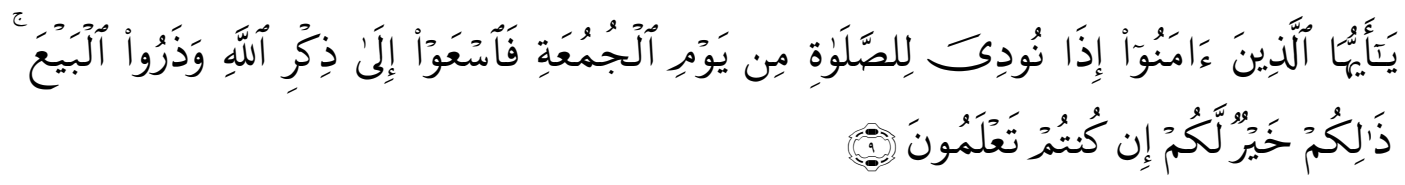

9. Hai orang-orang beriman, apabila diseru untuk menunaikan shalat Jum'at, Maka bersegeralah kamu kepada mengingat Allah dan tinggalkanlah jual beli[1475]. yang demikian itu lebih baik bagimu jika kamu mengetahui. 
Seruan perintah menenuaikan shalat Jumat bagi seluruh muslim berdasarkan ayat tersebut merupakan kewajiban. Waktu pelaksanaan shalat jumat mengambil waktu shalat zhuhur di hari yang lain. Shalat Jumat hanya dilaksanakan pada hari Jumat dengan dua jumlah rakaat. Meskipun pelaksanaannya sekali dalam seminggu, tetapi shalat Jumat memiliki keistimewaan. Ditengarai letak keistimewaan shalat Jumat karena didahului khutbah. Ketika khatib membacakan khutbah maka seluruh jama'ah diwajibkan mendengar dan menyimak sebaik-baiknya. Berbicara dan menegur-lisan maupun isyarat saat prosesi khutbah adalah hal yang terlarang. Pada ayat di atas juga, Allah memerintahkan bahwa jika sudah terdengar seruan (azan) untuk menenuaikan shalat Jumat maka ada tiga hal amalan yang mesti dikerjakan, 1). Bersegera, 2) berzikir, 3) meninggalkan jual beli. Ketiga amalan tersebut, oleh Allah ditegaskan bahwa itu lebih baik dibanding dengan amalan lainnya.

Mengenai kedudukan khutbah, para ulama berbeda pendapat. Pertama, pendapat yang menyatakan bahwa mengikuti khutbah wajib karena sebagai pengganti dua rakaat. Hal ini didasarkan pada asumsi bahwa shalat Jumat merupakan pengganti shalat zhuhur empat rakaat. Kedua, pendapat yang menyatakan bahwa khutbah bukan pengganti dua rakaat. Meskipun ada perbedaan asumsi mengenai kedudukan khutbah, akan tetapi kedua pendangan ini menegaskan khutbah pada hari Jumat wajib hukumnya. Tidak berlebihan jika ditegaskan, wajib hukumnnya ada khutbah pada pelaksanaan shalat Jumat, maka mendengarkan khutbah pun demikian.

Sebagaimana telah ditegaskan bahwa menyimak khutbah merupakan kewajiban. Walaupun demikian, dalam realitas keseharian nampak khutbah bukan hal yang penting bagi kaum muslimin pada umumnya. Alasannya, massif kaum muslimin di Kabupaten Sinjai sebagian besar jama'ah berada di luar mesjid saat khutbah berlangsung. Fenomena ini menimbulkan pertanyaan, mengapa hal itu itu terjadi? Apa yang menyebabkan?, mengapa fenomena itu seolah menjadi kebiasaan?. Jawaban asumtif dapat dikemukakan antara lain: 1) Pemahaman tentang shalat Jumat dan wajibnya menyimak khutbah kurang, 2) Materi khutbah 
yang tidak menarik, 3) integritas da'i yang kurang simpatik, 4) Fasilitas mesjid yang tidak memadai, atau karena ada faktor lain yang menjadi penyebabnya.

Di Kabupaten Sinjai, fenomena jama'ah jumat berada di luar mesjid saat khutbah berlangsung massif dapat diamati di seantero mesjid tempat pelaksanaan shalat jumat. Ditinjau dari perspektif teologis fenomena ini merupakan bentuk ketidakpatuhan dan ketidaktaatan yang berimplikasi pada dosa;kesalahan. Dalam aspek sosial-budaya, terjadi kontradiksi antara pemahaman nilai-nilai agama yang tidak terwujud dalam pengamalan dikeseharian muslim. Realitas ini menarik diteliti untuk mengetahui sebab-sebab mengapa fenomena tersebut terjadi.

\section{Landasan Teoritis}

\subsection{Shalat Dan Khutbah Jumat}

Hari Jumat sebagai salah satu dari tujuh hari yang dikenal manusia, bagi umat Islam merupakan hari khas. Jumat merupakan hari kaum muslimin melaksanakan ritual-ibadah yakni melaksanakan shalat jumat secara berjamaah. Pelaksanaan shalat jumat yang didahului khutbah telah menjadi pengetahuan umum bahwa syariat ini wajib, khususnya bagi muslim laki-laki. Sementara untuk muslimah, kewajiban menghadiri prosesi jumatan, ulama berbeda pendapat. Meskipun wajib atau tidak wajib menghadiri jumatan ada ikhtilaf para ulama, muslimah tidak salah atau berdosa berada dalam mesjid mendengar khutbah dan shalat jumat berjamaah.

Untuk melaksanakan shalat Jum'at, kaum muslim berkumpul di sebuah masjid. Biasanya mereka datang lebih awal untuk mendengar khutbah. Setelah khutbah kemudian dilaksanakan shalat jumat secara berjamaah. Fenomena pelaksanaan jumatan di daerah perkotaan dan pedesaan nampak ada perbedaan. Di perkotaan, keadaan jamaah jumat bervariasi. Variasi jumlah jamaah, asal-usul jamaah, cara berpakaian cenderung berubah, dan materi khutbah. Sedangkan di daerah pedesaan, jamaah shalat Jum'at lebih homogen, stagnan dari segi jumlah, dan materi khutbah cenderung monoton.

Status wajib melaksankan shalat jumat secara berjamaah, dipimpin seorang imam dengan suara yang jahar dan jumlah dua rakaat, merupakan acara 
“inti” jumatan. Sementara menghadiri/menyimak khutbah Jum'at, dianggap tidak sewajib pelaksanaan shalat dua rakaat. ada ikhtilaf ulama mengenai hukum mengikuti khutbah dalam prosesi jumatan. Dalam prosesi jumatan, ada ulama berpendapat bahwa khutbah tidak termasuk rukun. Karena bukan bukan rukun maka hukumnya tidak wajib. Sementara ulama lain, menganggap bahwa khutbah nerupakan rukun shalat jumat. Sebagai rukun maka wajib mengikutinya. Selain itu, dua khutbah sebelum shalat jumat merupakan pengganti dua rakaat (sebagaimana jumlah rakaat shalat dhuhur).

Terdapat beberapa tulisan yang telah dirilis tentang shalat jum'at, akan tetapi rata-rata fokus penelitian tersebut hanya menelaah tentang dalil-dalilnya, syarat-syaratnya, rukun-rukunnya, dan problematikanya. Sebagian besar pembahasannya "beraroma" fiqih. Untuk itu penting diketahui tentang sejarah awal diperintahkannya shalat jum'at sampai pada perintah untuk menunaikannya sekaligus sejarah penentuan hukumnya sebagai pengganti shalat dzuhur.

Sebelum Hijrah Rasulullah SAW telah mengutus Mush'ab ibn Umair bin Hasyim ke Yastrib; Madinah untuk mengajarkan Al-Qur'an. Selain mengajarkan Al-Qur'an, suatu ketika dia meminta ijin pada Nabi Saw untuk menyelenggarakan ibadah shalat Jumat. Rasul dengan senang hati mengijinkannya. Jadi Mush'ab bin Umair bin Hasyim adalah orang yang pertama kali melakukannya (Ali ibn Ahmad ibn Hazam al-Zhohiri: 1990, 72).

\subsection{Dalil-dalil Shalat Jum'at}

a. Dalil Al-Qur'an

Dalil yang mensyariatkannya dalam al-Qur'an Allah Berfirman dalam Q.S al Jumu'ah/62: 9,

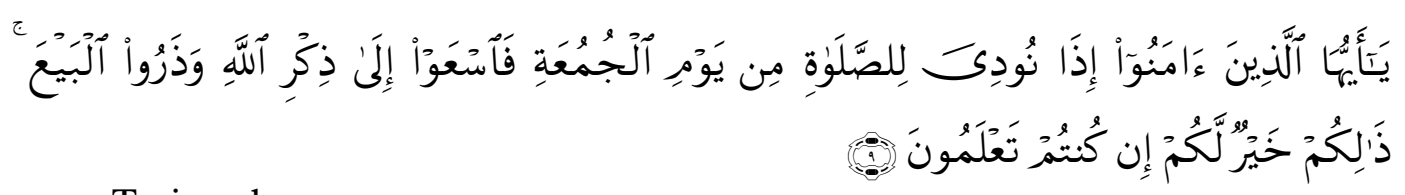

Terjemahnya:

Wahai orang-orang yang beriman, apabila telah diseru untuk melakukan shalat pada hari jum'at, maka segerahlah kamu mengingat Allah dan tinggalkan jual beli, yang demikian itu lebih baik bagimu jika kamu mengetahuinya. 
Sebagaimana tersurat dalam ayat ini, Allah menyeruh/memerintahkan orang-orang yang mengaku beriman apabila mendengar seruan untuk melaksanakan shalat di hari Jumat agar bersegera menghadirinya. Meninggalkan jual beli atau urusan yang bersifat duniawi untuk segera menghadiri majelis dalam mesjid untuk berzikir-dan mendengar khutbah sebagai salah satu urusan yang bersifat ukhrawi.

Ayat 9 Surah Al Jumu'ah ini merupakan satu-satunya dalil naqli mengenai kewajiban menghadiri ritual hari jumat bagi muslim yang benar-benar beriman dalam al Qur'an. Dalam buku Asbab an nujul al Qur'an dijelaskan bahwa pernah suatu ketika Nabi saw sedang berkhutbah, tiba-tiba datang rombongan dagang tiba di Madinah. Kedatangan rombongan dagang tersebut menyebabkan sebagian orang yang ada dalam mesjid, berhamburan keluar untuk berbisnis dengan kafilah dagang tersebut. Sementara sebagian lainnya tetap dalam mesjid mendengar khutbah. Oleh sebagian besar mufassir, kejadian ini yang menyebabkan ayat 9 surah al Jumu'ah turun, sebagai peringatan bagi kaum muslimin.

\section{b. Dalil Hadis}

selain dalil yang ada dalam qalamullah, pelaksanaan shalat jumat banyak disebutkan dalam hadis-hadis Nabi saw. Hadits Abu Daud, yang berbunyi:

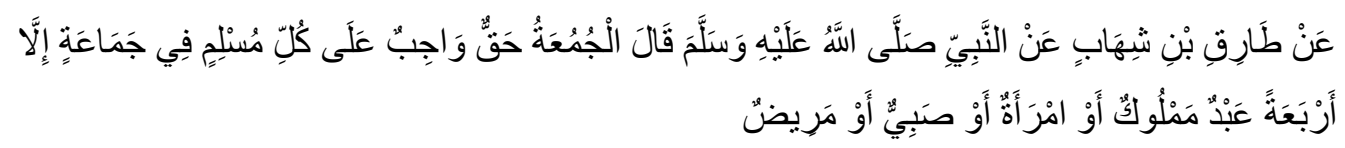

Artinya:

Dari Thariq bin Syihab, dari Rasulullah Saw bersabda: Shalat jum'at itu wajib bagi setiap muslim dalam jamaah, kecuali empat yaitu: hamba sahaya, wanita, anak-anak dan orang sakit.(HR Abu Daud)

Lebih lanjut beliau menjelaskan pula setelah menyampaikan hadis ini bahwa sesungguhnya Thariq bin Syihab melihat Rasulullah tapi tidak mendengarkan satupun hadis Rasul. Menanggapi hal tersebut, Imam Nawawi mengomentari hadis Thariq diatas dengan mengatakan “ pernyataan Abu Daud tersebut tidak merusak keabsahan hadis, karena jika benar dia tidak mendengar satu hadispun dari Rasulullah maka hadisnya adalah mursal shahaby, dan mursal shahaby dapat menjadi hujjah menurut mazhab syafi'i dan seluruh ulama, kecuali Abu Ishak al-Isfirayini” (Majmu’ Syarh Al Muhadzdzab: 1425, 349). 
Syaikh Al Albani menukilkan pernyataan Imam Nawawi dari Imam Az Zaila'i di dalam Nashbu Ar Rayah, 2/199, berbunyi: Imam Nawawi berkata dalam Al Khulashah,'Hal ini tidak merusak keabsahannya; karena ia termasuk mursal shahabi dan mursal shahabi hujjah. Sedangkan hadits ini shahih atas syarat Syaikhan (Al Bukhari dan Muslim) (Syaikh Al Albani: 1405, 55).” Kemudian Syaikh Al Albani berkomentar: "Seakan-akan karena inilah hadits ini dishahihkan banyak ulama, sebagaimana terdapat di dalam At Talkhish"

Hadits ini juga diriwayatkan Ad Daraquthni dalam Sunan-nya, no. 164 dan Al Baihaqi dalam dua pembahasan; Bab : Man Tajibu 'Alaihi Al Jum'at, 3/246, no. 5578, dan Bab : Man La Talzamuhu Al Jum'at, 3/360, no.5630, ia dan berkata,"Hadits ini walaupun terdapat irsal, namun ia adalah mursal yang diterima, karena Thariq termasuk tabi'in pilihan dan orang yang melihat Nabi Shallallahu 'alaihi wa sallam, namun tidak mendengar haditsnya. Dan hadits ini memiliki syahid (riwayat penguat dari sahabat lainnya)" Sedangkan Syaikh Al Albani menambahkan bahwa Al Maqdisi mengeluarkannya juga dalam Al Mukhtarah dari Ishaq bin Manshur secara mursal.

Imam Al Hakim di dalam Mustadrak, 1/288, juga meriwayatkan hadits ini dari jalur periwayatan Ubaid bin Muhammad Al 'Ijli dari Al Abas bin Abdul 'Adzim dengan sanadnya sampai kepada Thariq bin Syihab dari Abu Musa Al Asy'ari secara maushul (bersambung) sampai kepada Nabi Shallallahu 'alaihi wa sallam dan berkata,"Shahih sesuai syarat Syaikhan," dan disepakati Imam Adz Dzahabi. Namun riwayat ini dinyatakan oleh Imam Al Baihaqi, dan Al Albani sebagai riwayat yang syadz, karena menyelisihi riwayat Abu Dawud yang mursal.

Selain dari hadis diatas, ada beberapa hadis yang menunjukkan perintah shalat jum'at yang kesemuanya melalui jalur Hadits yang diriwayatkan oleh Thariq bin Syihab ini memiliki syawahid (jalan periwayatan penguat dari sahabat lain), diantaranya:

c. Dalil Dalil atsar sahabat dan tabi'in Atsar yang diriwayatkan dari Umar bin Al-Khathab radhiallahu 'anhu, ia berkata,

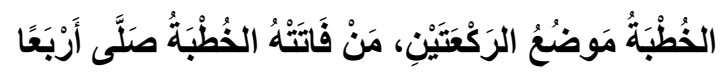

Artinya: 
"Khotbah merupakan tempat dua rakaat. Siapa saja yang terlewat dari khotbah maka hendaklah dia shalat empat rakaat."

Dalam riwayat yang lain,

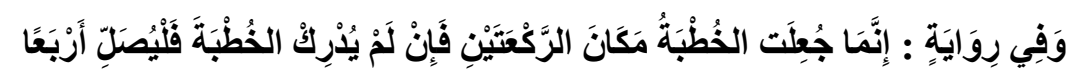

Artinya:

"Khotbah itu tidak lain dijadikan pengganti dua rakaat. Jika seseorang tidak mendapatkan khotbah maka hendaklah dia shalat empat rakaat."

Atsar di atas menunjukkan bahwa dua khotbah merupakan pengganti dari dua rakaat shalat zuhur.Oleh karena itu, keduanya adalah perkara wajib karena merupakan bagian dari shalat, begitu pula hukum penggantinya.Atsartersebut adalah atsar yang sanadnya terputus dan tidak bisa dijadikan dalil. Kalaupun atsar tersebut benar-benar perkataan sahabat, maka masih tetap ada perselisihan mengenai penggunaanya sebagai dasar hukum. Adapun penyebuatan atsar tersebut di sini hanyalah sebagai isyarat bahwa sebagian ahli fikih menggunakannya sebagai dalil dalam permasalahan ini.

\subsection{Hukum dan Waktu Shalat Jum'at}

Berdasarkan konsep al-Qur'an dan hadis, ulama sepakat bahwa shalat jum'at hukumnya fadhu 'ain bagi orang-orang yang telah sempurna syaratsyaratnya (akan dibahas lebih lanjut pada tema khusus). Sebagaimana yang diungkapkan oleh abdurrahman ibn muhammad 'aud al-jaziri bahwa Sholat jumat hukumnya fardlu bagi orang yang telah sempurna syarat-syaratnya menurut kesepakatan ulama madzhab. Sejalan dengan pendapat diatas Muhammad Ja'far Shadiq mengatakan bahwa pada hakikatnya hukum shalat jum'at adalahFardhu 'Ain, artinya kewajiban individu mukallaf (muslim, baligh, berakal) kecuali 6 golongan:
a. Hamba sahaya (budak belian)
b. Perempuan
c. Anak kecil (yang belum baligh)
d. Orang sakit yang tidak dapat menghadiri Jumat
e. Musafir, yakni orang yang sedang dalam perjalanan jauh
f. Orang yang udzur jum'at, seperi ada bencana alam atau bahaya. 
Pengecualian ini ditetapkan oleh sabda Nabi SAW:

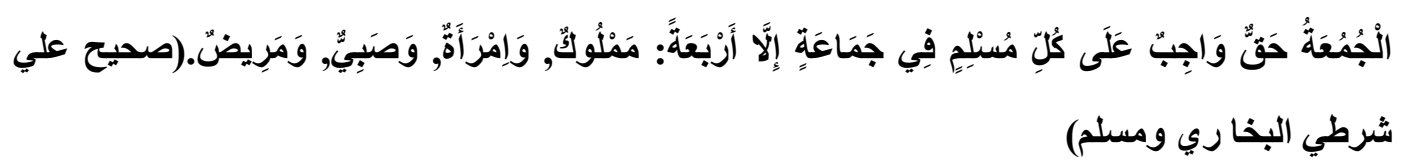

Artinya:

"Jum'at itu hak yang wajib bagi setiap Muslim dengan berjama'ah kecuali empat orang, yaitu: budak, wanita, anak kecil, dan orang yang sakit."

Adapun bagi musafir, dan ada yang $u d z u r$, karena perbuatan Rasulullah SAW, apabila mengadakan perjalanan jauh, dan sampai hari jum'at beliau dan para sahabatnya tidak menunaikan shalat jum'at, melainkan hanya shalat Zuhur, demikian pula ketika kejadian badai hari jum'at dikota madinah, Beliau menganjurkan para sahabatnya shalat masing-masimg di rumah mereka. Kewajiban shalat jum'at merupakan bentuk pemindaian dari pada pendapat ulama islam. Para ulama sependapat bahwa hukum shalat jum'at adalah fardhu 'Ain dan jumlah rakaatnya dua (Sayyid Sabiq, 495). Hal ini berdasarkan firman Allah dalam QS al Jumu'ah/62: 9 sebagaimana telah dikutip sebelumnya.

Merujuk QS al Jumu'ah/62: 9 dan ulasan para ulama, maka dapat disimpulkan hukum shalat jumat adalah:

a. Jum'at Wajib 'Aini bagi yang memenuhi syarat-syarat yang telah ditetapkan. Orang yang meniggalkannya tanpa udzur adalah dosa besar.

b. Bila sudah dikumandangkan adzan jum'at, wajib segera untuk mendengar khutbah dan menunaikan shalat jum'at.

c. Sesudah adzan jum'at berkumandang haram hukumnya bagi yang wajib jum'at melakukan kegiatan yang bersifat duniawi seperti jual beli atau pekerjaan lainnya.

Ketiga point hukum mengenai shalat jumat tersebut, dikuatkan pula oleh hadis menerankan bahwa Rasulullah SAW memberikan ancaman bagi orang yang meninggalkan jum'at tanpa udzur, antara lain:

a. Nabi SAW, bercita-cita menyuruh orang mencari kayu bakar dan yang lainnya mengumandangkan adzan, lalu Beliau akan membakar rumah orang yang tidak pergi jum'at. 
b. Nabi SAW, bersabda dari mimbarnya, "Hendaklah kaum-kaum itu berhenti meninggalkan jum'at atau Allah kunci hati-hati mereka dan mereka dijadikan orang-orang yang lalai.,"

c. Barang siapa meninggalkan tiga jum'at karena menyepelekannya maka Allah akan menutup hatinya (Sayyid Sabiq, 460).

(Wahbah Zuhaily: 1418, 141) menjelaskan bahwa Kewajiban shalat jum'at tidak dapat terpisah dari al-Quran yang memposisikan hari itu dengan sangat istimewa, yakni nama salah satu suratnya (al-Jumu'ah) surat nomor ke-62 yang turun sesudah hijrah (madaniyah), terdiri dari 11 ayat dan 180 kalimat. Perintah yang berkaitan langsung dengan shalat jum'at terdapat pada ayat kesembilan. Lebih lanjut, Zuhaily menjelaskaan bahwa Shalat jum'at dalam pelaksanaannya sama dengan shalat fardhu lima kali sehari pada rukun, syarat dan adabnya. Namun terdapat kekhususan pada syarat wajibnya dan syarat sahnya.

Muhammad Ibn Jarir al-Thabari memberi penjelasan mengenai kalimat “ "maka bersegeralah kamu kepada mengingatAllah" terkait dengan hukum shalat jum 'at, berarti bersegera dalam berjalan yakni melakukan perjalanan dengan cepat menuju ke tempat shalat tanpa melalaikannya (Muhammad Ibn Jarir al-Thabari: 2000, 380). Hal ini dipertegas dalam hadits riwayat Ibnu Majah, Nabi saw: Apabila shalat sudah ditegakkan maka janganlah kamu datanginya dan kalian bersegera dalam berjalan serta datangilah dengan berjalan dan hendaklah tenang dalam berjalan lalu berapa kalian dapat dari shalat jamaah maka lakukan sedangkan yang tertinggal sempurnakan (Ibnu Majah: 767, 493).

\subsection{Rukun dan Syarat Shalat Jum'at}

a. Rukun shalat jum'at

Sama halnya dengan syarat-syarat shalat Jum'at di atas, rukun-rukun (fardlu) shalat Jum'at tidak berbeda dengan rukunrukun shalat maktubah yang lain. Para ulama'pun beragam dalam memformulasikan rukun-rukun shalat Jum'at tersebut. Rukun ini oleh Syafi'i dibagi kepada dua klasifikasi, fi'liyah dan qauliyah.

Rukun fi'liyah merupakan sesuatu rukun yang sifatnya gerakan-gerakan tertentu oleh mushalli. Sedangkan rukun qauliyah adalah ucapan-ucapan tertentu 
dalam shalat. Adapun rukun shalat Jum'at adalah sebagai berikut (M. Rifa'i: 1993, 101):

1. Sebagaimana rukun shalat yang lain

2. Khutbah dua kali yang duduk diantara keduanya

3. Shalat dua raka'at, dengan berjama'ah

b. Syarat-syarat shalat jum'at

Syarat shalat jum'at adalah ketentuan-ketentuan yang merupakan syarat wajib dan sahnya shalat jum'at.Adapun syarat-syarat tersebut merupakan intisari daripada hadis dan pendapat para ulama terkait dengan ketentuan-ketuan shalat $\mathrm{j}$ um'at.Abdurrahman Ibn Muhammad 'Aud Al-Jazirimenuturkan bahwa syaratsyarat shalat jum'at menurut imam madzhab dapat dilihat sebagaimana berikut (Abdurrahman Ibn Muhammad, 335-336):

Menurut Mazhab Hanafy bahwa syarat sholat jumat adalah kesemua dari syarat shalat lima waktu, dan beberap syarat yang merupakan tambahan dari syarat sholat, dan hal tersebut terbagi dua, yaitu:

a. Syarat wajib yaitu:

1. Laki-laki.

2. Merdeka (bukan budak).

3. Sehat

4. Iqomat di tempat dilaksanakannya sholat jumat (berdiam/muqim tidak sedang melakukan perjalanan/safar).

5. Berakal (tidak gila).

6. Baligh

\subsection{Keutamaan/Hikmah dan Karaktristik Shalat Jum'at}

Adapun diantara hikmahnya shalat jum'at disyariatkan adalah untuk mengkokohkan pemikiran berjamaah. Mampu mengumpulkan ummat islam, saling mengenal dan harmonis. Menyatukan opini ummat islam dan melatih loyalitas mereka kepada pemimpin, sekaligus berpegang teguh kepada tuntutan para pemimpin. Mengingatkan kaum muslimin kepada syariat islam, sebagai undang-undang, hukum, akhlak, adab, dan dasar perilaku. Kemudian, untuk melakasanakan perintah-perintah jihad dan semua kebutuhan demi kebaikan 
ummat islam, baik di luar atau didalamnya, serta memerintahkan kepada kebaikan dan mencegah yang mungkar. Intinya, nasehat yang diulang-ulang dan peringatan yang terus-menerus disetiap minggu memiliki dampak yang sangat nyata dalam memperbaiki individu dan jamaah. Sebagaimana Firman Allah SWT dalam surat Adz-Zariat :55 :

Terjemahnya:

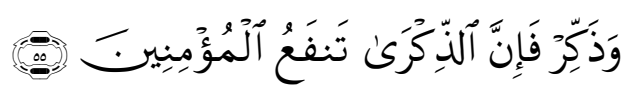

Dan tetaplah memberi peringatan, karena sesungguhnya peringatan itu bermanfaat bagi orang-orang yang beriman.

Beranjak dari hikmah diatas beserta manfaat shalat jum'at dan hukumnya, ummat islam dianjurkan untuk bersegera dalam melaksanakan shalat jum'at untuk mewujudkan dan merealisasikan tujuan-tujuan dan maksud mulia dari hikmah pelaksanaan shalat juma't. disamping mewujudkan tujuan-tujuan islam, islam juga memberikan alternatif yang sangat tinggi yaitu pahala atau ganjaran yang hanya akan didapatkan di Negri Akhirat. Bersegera dalam merupakan anjuran, datang sebelum waktunya merupakan keutamaan, sementara meninggalkan pekerjaan berdagang atau berbagai rutinitas kehidupan merupakan perintah yang diharuskan agar tidak menjadi penyebab timbulnya rasa malas dan mengangapnya remeh atau bahkan tidak melaksanakan shalat jum'at.

Kewajiban untuk bersegera melaksanakan shalat jum'at, menurut mayoritas ulama, dimulai ketika azan berkumandang dihadapan khatib jum'at.Sementara menurut mazhab Hanafy, dimulai dari azan pertama ketika matahari tergelincir, kecuali jika rumahnya jauh dari masjid maka diharuskan baginya unutk bersegera sebatas dapt melakukan yang wajib (Al-Mugny, 297). Berangkat lebih awal untuk melaksanakan shalat jum'at memiliki beberapa derajat pahala. Rasulullah SAW bersabda: Siapa yang mandi di pagi hari jum'at, seperti mandi besar lalu pergi untuk menunaikan shalat jum'at seakan-akan ia berkurban dengan seekor unta gemuk. Siapa yang berangkat pada gelombang kedua, ia seperti berkurban dengan seekor sapi. Siapa yang berangkat pada gelombang ketiga, ia seperti berkurban dengan seekor domba kibas jantan. Siapa yang 
berangkat pada gelombang keempat, ia seperti berkurban dengan seekor ayam. Siapa yang berangkat pada gelombang kelima, ia seperti berkurban sebutir telur. Jika imam telah keluar (untuk siap berkhutbah) maka para malaikat akan datang mendengarkan dzikir.

Waktu yang dianjurkan untuk pergi menunaikan shalat jum'at menurut pendapat ulama, menurut Wahbah Zuhaily bahwa sekelompok diataranya mayoritas ulama selain mazhab maliki berkeyakinan bahwa waktu-waktu yang dianjurkan itu dimulai dari awal hari sampai tergelincirnya matahari, dan terbagi menjadi lima bagian. Masih menurut Dr. Wahbah Zuhaily bahwa mayoritas ulama menganjurkan untuk berangkat di awal siang.Namun, pendapat yang paling jelas seperti yang disebutkan mazhab maliki bahwa beberapa jam sebelum tergenlincirnya matahari, karena jam ditinjau dari segi syariat maupun dari segi bahasa adalah bagian dari waktu. perlu dicatat bahwa tidak pernah disebutkna oleh para sahabat bahwa beliau SAW pergi untuk menunaikan shalat jum'at sebelum matahari terbit atau beberapa saat setelahnya.

Melaksanakan shalat jum'at dengan adab-adabnya dapat mengampuni dosa-dosa seorang mukmin yang dilakukan diatara dua jum'at, sebagaima yang diriwayatkan oleh Imam Muslim dari Abu Hurairah Rasulullah SAW bersabda:

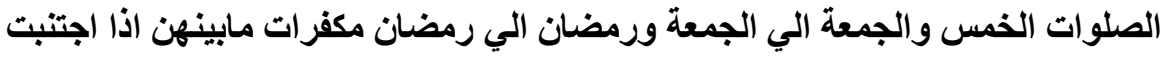

Artinya:

Shalat lima waktu, dari jum'at ke jum'at, dari ramadhan ke ramadhan dapat mengampuni dosa-dosa yang dilakukan diatara keduanya, selagi menjauhi dosa-dosa besar.

Dalam hadis yang berbeda yang diriwayatkan oleh Muslim dari Abu Hurairah, diriwayatkan pula oleh Ahmad dari Abi Ayyub dengan lafadz yang berbeda, diriwayatkan pula oleh at-Thabrany dalam kitab al-Awsath dari hadis Ibnu Umar, diriwayatkan pula oleh al-Bazzar dan At-Thabrany dalam kitab alawsath dari hadis Ibnu Abbas dan diriwayatkan pula oleh Abu Daud dari Abdullah bin Amru bin Ash, Rasulullah SAW bersabda: "Man igtasala tsumma ata> al-jum'ata hatta> yafruga al-imamu min khutbatihi, tsumma yushally ma'ahu, gufira lahu ma bainahu wa baina al-jum'ati al-ukhra> wa fadlu, ayyu 
ziyadata tasalasata ayyamin”, artinya: "Siapa yang mandi lalu pergi menunaikan shalat jum'at hingga imam selesai dari khutbahnya, lantas ia ikut shalat bersamanya akan diampuni dosa-dosanya yang dilakukan diantara hari itu dan hari jum'at yang akan datang, serta ditambah tiga hari (Subulu Assalam: 236)."

Pada hari jum'at pula terdapat waktu dikabulkannya do'a orang yang berdo'a tepat pada waktu yang dimaksudkan, sebagaimana hadis yang telah disepakati oleh imam hadis, yang menurut Dr. Wahbah Zuhaily bahwa hadis tersebut muttafaq alaihi dari Abu Hurairah r.a, Rasulullah Saw menyebutkan hari hari jum'at, lalu Beliau bersabda bahwa didalamnya ada waktu yang sangat baik bagi seorang hamba muslim, sementara ia sedang melakukan shalat. Jika ia meminta sesuatu kepada Allah, niscaya Allah akan memberikan kepadanya. Nabi Saw memberi isyarat dengan tangannya bahwa hal itu sangat mudah bagi Allah (Subulu Assalam: 54).

Sementara untuk menentukan waktu ini, terdapat beberapa pendapat yang paling shahih, sebagaimana tah ditetapkan dari hdis Abi Burdah dalam Shahih Muslim, yaitu waktu imam duduk diatas mimbar sampai selesai shalat./atau sampai ila an yuqdha shalatuhu ( sampai dia ingin melaksanakan shalatnya).

Karaktristik hari jum'at.Hari jum'at memiliki banyak keistimewaan, yaitu sekitar seratus keistimewaan yang dijelaskan oleh imam As-Suyuty dalam sebuah ktab khusus berjudul Khususiyaat al yaum al jum'ah (keistemewaan hari jum'at) (Imam As-Suyuti: 1964). Disebutkan keistimewaan hari jum'at diataranya; pada hari jum'at arwah-arwah berkumpul, dianjurkan berziarah kubur, mayat dihentikan dari siksa kubur, api neraka jahannam tidak menyala-nyala pada hari jum'at, dan pada hari itu para penghuni syurga berkunjung kepada Tuhan mereka, Allah Swt (Ad-Dur al-Mukhtaar: 773).

Berpartisipasi dalam ibadah, siapa yang berusaha untuk pergi menunaikan shalat jum'at menyiapkan semua keperluannya, lalu tujuan terbesarnya adalah melaksanakan shalat jum'at maka ia akan mendapat pahala untuk usahanya itu. Mazhab hanafay mengatakan dengan demikian bisa diketahu bahwa siapapun yang mengikat dirinya dengan ibadah maka pelajaran berharga bagi yang banyak melakukannya (Ad-Dur al-Mukhtaar, 772). 


\subsection{Paradigma Teologis Mendengarkan Khutbah}

Shalat jum'at sah dilaksanakan apabila didahului dengan dua khutbah, para jama'ah diharuskan mendengarkan khutbah. Mereka dilarang bicara pada saat khutbah juga dilarang mencegah orang lain berbicara saat khutbah. Adapun orang yang tidak mengikuti dan mendengarkan khutbah tetap dianggap mengikuti shalat jum'at sekalipun tidak mendengarkan khutbah. Sebgaimana pendapat para imam mazhab berikut:

Mazhab syafi'i, Maliki dan Hambali: berpendapat bahwa apabila seseorang tertinggal pada shalat jum'at dan mendapati imam sudah memulai shalat jum'at, hendaknya segera bertakbiratul ihram. Jika sempat ruku bersama imam ia terhitung telah mendapat satu rakaat, namum apabila itu dirakaat kedua hendaknya ia memanbahkana satu rakaat lagi setelah salam. Adapun jika makmun datang sedangkan imam telah mengangkat kepalanya dari rakaat kedua, hilanglah kesempatannya untuk memperoleh shalat jum'at. Walaupun demikian, ia diharuskan untuk segera melaksanakan shalat dengan niat untuk shalat dzuhur empat rakaat.

Namum menurut Abu Hanifah dan Abu Yusuf bahwa barangsiapa mendapatkan imam dengan tasyahhud akhirnya dan menambahkan dua rakaat setelah salamnya imam, maka shalatnya tersebut dihukumi sebagai shalat jum'at meskipun hanya mendapatkan tasyahhud akhir dari imam. Dengan catatan bahwa seorang muslim tidak diperkenankan mengambil pendapat tersebut sebagai alsan untuk terlambat datang kemesjid pada hari jum'at atau dengan alasan tidak ingin mendengarkan khutbah, pendapat ini hanya dapat diamalkan ketika sedang ketiduran ataupun dalam perjalanan jauh atau tidak menyadari bahwa hari itu adalah hari jum'at. Adapun yang tidak memiliki alasan yang dapat dibenarkan maka hendaknya datang lebih awal kemesjid dan mendengarkan khutbah karena pahalanya lebih tinggi daripada yang datang lebih akhir (Hasbiyallah, 65).

\section{Metode Penelitian}

Berdasarkan judul "Pelaksanaan Shalat dan Khutbah Jumat di Sinjai (Telaah Fenomena Nongkrong di Luar Mesjid Saat Khutbah)", maka jenis 
penelitian ini adalah Field Research kualitatif. Sugiyono menjelaskan, penelitian kualitatif sering disebut penelitian naturalistik karena penelitiaan dilakukan pada kondisi alamiah. Paradigma dasar penelitian kualitatif memandang realitas sosial sebagai sesuatu yang holistik, kompleks, dinamis, dan penuh makna (Sugiyono: 2013, 1). Adapun lokasi penelitian bertempat di wilayah pemerintahan daerah Kabupaten Sinjai.

Pada penelitian kualitatif, permasalahan yang dibawa oleh peneliti masih bersifat sementara, maka teori yang digunakan dalam penyusunan proposal juga masih bersifat sementara, dan akan berkembang setelah peneliti memasuki lapangan atau konteks sosial (Sugiyono: 2013, 78-81). Sehubungan dengan itu, dalam analisis dan pembahasan penelitian ini, ada beberapa pendekatan (Sartono Kartodirdjo: 1993, 4) teori keilmuan yang akan digunakan dalam analisis pembahasan, yakni pendekatan teori-teori sosiologi, antropologi, dan teologi.

Untuk sementara pendekatan tiga teori tersebut dipandang cukup menjadi "alat bedah" terhadap fenomena nongkrong di luar mesjid saat khutbah Jumat sedang berlangsung. Jika pada perkembangan selanjutnya, ketiga pendekatan teori dimaksud tidak cukup menjadi alat memahami fenomena yang ada maka tidak menutup kemungkinan digunakan pendekatan teori-teori dari disiplin ilmu tertentu yang memiliki keterkaitan langsung pada realitas yang diamati.

Sumber utama data pada penelitian ini adalah para jama'ah mesjid, baik yang ada dalam kota Sinjai maupun yang berada di luar kota atau mesjid dengan daya tampung jama'ah yang besar maupun mesjid dengan daya tampung kecil. Untuk kajian pelaksanaan khutbah dan shalat Jumat secara normatif dan teologis serta implikasi fiqih ibadah-nya dalam syariat Islam, maka sumber data yang digunakan yakni bersumber pada literatur dan referensi karangan/kitab beberapa ulama yang dianggap mumpuni dalam bidang ini. Perpaduan sumber mengenai konsepsi normatif pelaksanaan khutbah dan shalat Jumat dan fenomena realitas yang di lapangan, diharapkan dapat memberikan generalisasi yang dapat dipertanggungjawabkan.

Peneliti kualitatif harus bersifat perspektif emic, artinya memperoleh data bukan "sebagaimana seharusnya", bukan berdasarkan apa yang dipikirkan oleh 
peneliti, akan tetapi berdasarkan sebagaimana adanya yang terjadi di lapangan, yang dialami, dirasakan, dan difikirkan oleh partisipan/sumber data (Sugiyono: 2013, 47). Saran Sugiyono tersebut, menjadi tuntunan dalam proses menemukan sumber data lisan berupa wawancara.

Teknik pengolahan dan analisis pada sumber-sumber data dilakukan dengan cara direduksi, dirangkum, dan disusun secara sistematis sehingga didapatkan gambaran yang utuh pada konstruksi teoritis sebagaimana terkandung dalam tujuan penelitian. Setelah itu, dilakukan klasifikasi data yaitu mengelompokkan data-data berdasarkan ciri khas masing-masing sesuai dengan tujuan formal penelitian (Ikbal Hasan: 2002, 162-163). Data yang telah terkumpul akan diseleksi, dianalisis untuk memperoleh data yang akurat. Analisis data dilakukan secara berulang-ulang dan berkesinambungan agar data benar-benar valid dan meyakinkan.

\section{Pembahasan}

\subsection{Alasan-Alasan Responden}

Pada kajian teori mengenai pelaksanaan khutbah dalam prosesi shalat Jumat, didapatkan bahwa khutbah merupakan item acara yang urgen. Pelaksanaan khutbah diawal waktu sebelum shalat jumat dua rakaat dilakukan menunjukkan khutbah bagian integral dari seluruh prosesi ritual jum'at-an. Lepas dari perdebatan fuqaha mengenai wajib atau tidak wajib mengikuti khutbah, tidak dapat menjadi argumentasi memandang khutbah sebagai hal yang sepele. Dalam kata lain, tidak sempurna pelaksanaan ritual shalat jumat jika seseorang tidak mengikuti/menyimak khutbah.

Seruan Allah dalam QS Al Jumu'ah/62: 9 berorientasi pada perintah yang tegas bagi orang-orang yang mengaku beriman agar: bersegera menghadiri shalat jumat, memperbanyak mengingat Allah, dan meninggalkan urusan jual beli. Ketiga pokok perintah tersebut menujukkan intisari amalan dalam ritual jumat. Integrasi tiga intisari itu jauh lebih baik dan penting dilakukan sebagaimana ditegaskan oleh Allah pada frase terakhir firman-Nya ayat 9 yakni: itu lebih baik 
jika kamu mengetahui. Dalam makna lain, banyak rahasia spiritual yang penuh berkah; manfaat dalam kehidupan bagi orang yang melaksanakannya.

Berdasarkan referensi hadis-hadis didapatkan penegasan secara umum bahwa menghadiri prosesi jumat-an (mendengar khutbah dan shalat jumat) lebih awal sebelum azan dikumandangkan adalah lebih baik. Dikatakan lebih baik karena janji akan pahala yang besar dan banyak akan dicatatkan/diberikan. Kebalikannya, orang yang datang belakangan/terlambat akan mendapat pahala yang kecil dan sedikit. Artinya, bagi yang datang belakangan/terlambat adalah orang-orang yang menyia-nyiakan kesempatan dan peluang mendapatkan pahala.

Sebagaimana telah diuraikan sebelumnya, penelitian ini difokuskan untuk memahami fenomena kebiasaan nongkrong di luar mesjid saat khutbah jumat sedang berlangsung. Untuk mengetahui perspektif atau pendapat responden maka ada lima rumusan pertanyaan-yang dirasa cukup komprehensif akan diberikan, meliputi: 1) Pengetahuan responden tentang Khutbah, 2) Pendapat responden tentang materi yang disampaikan oleh khatib, 3) Penyimakan responden tentang retorika khatib, 4) Penilaian responden tentang integritas prilaku khatib, 5) Pendapat responden mengenai fasilitas dalam mesjid.

Kelima macam pertanyaan itu, menjadi acuan untuk mengetahui dan menjawab pertanyaan inti dalam penelitian ini yakni mengapa beberapa orang lebih suka nongkrong di luar mesjid saat khutbah berlangsung, sekaligus menjadi informasi penting cara untuk mengurangi atau menghilangkan kebiasaan tersebut. Dalam pelaksanaan penelitian ini, data yang berhasil diperoleh sebanyak 46 orang responden yang berasal dari wilayah Sinjai. Rata-rata yang dijadikan responden berusia 17-35 tahun, sisanya berusia 35 tahun ke atas. Usia 17-35 tahun menjadi sasaran utama perolehan data dengan alasan karena berdasarkan observasi awal, interfal usia ini yang sering nongkrong di luar mesjid saat khutbah berlangsung.

Berdasarkan data yang ada maka diperoleh keterangan-keterangan mendasar mengenai pendapat, alasan, dan harapan para responden berkaitan dengan 5 (lima) pokok yang menjadi inti pertanyaan, sebagaimana telah dituliskan sebelumnya. Adapun pendapat, alasan, dan harapan para responden dapat disekripsikan sebagai berikut: 


\section{Pengetahuan Tentang Urgensi Khutbah}

Ada 23 orang yang memberikan keterangan mengenai pentingnya khutbah dalam prosesi shalat jumat. 15 orang mengatakan, khutbah itu wajib didengar dan dikuti. Mereka memberi keterangan bahwa mendengar khutbah itu wajib didengar/diikuti sebab dapat menjadi media untuk mendekatkan diri kepada Allah, mendengar khutbah merupakan berkah, mendengar khutbah pahala bertambah, wahana menambah ilmu agama, termasuk rukun jumatan, mendengar khutbah dapat mencerahkan hati dan pikiran. Sementara itu, ada 8 orang yang pengetahuannya mengenai khutbah kurang baik. Mereka mengatakan: shalat yang terpenting, haruskah masuk mesjid untuk mendengar khutbah?, tidak tahu jika khutbah jumat itu bermanfaat. Selanjutnya, sebanyak 23 orang responden tidak memberikan keterangan, mengenai pengetahuan mereka tentang urgensi khutbah pada shalat jumat.

Berdasarkan pemaparan data tersebut, pada dasarnya jama'ah mengetahui bahwa mendengar/mengikuti khutbah itu wajib dan penting. Khutbah merupakan media untuk mendapatkan pahala, taqarrub ilallah, menambah pengetahuan agama, dan acara yang dapat memberikan pencerahan hati (batin) dan pikiran (akal). Alasan-alasan ini, memberikan gambaran kesadaran para jama'ah akan berkah;manfaat mengikuti dan mendengar khutbah dalam mesjid.

Di sisi lain, responden dengan pengetahuan yang kurang mengenai urgensi khutbah dapat diasumsikan menjadi penyebab mereka tidak masuk dalam mesjid menyimak khutbah yang disampaikan oleh khatib. Selanjutnya, 23 responden yang tidak memberikan keterangan dapat dikategorikan sebagai jamaah yang kurang atau tidak sama sekali mengetahui mengenai urgensi khutbah. Sehingga dapat ditengarai bahwa sebab mereka sering/selalu di luar saat khutbah berlangsung murni karena ketidaktahuan.

\section{Materi Khutbah}

Terdapat 16 responden yang memberikan pendapat mengenai materi khutbah jumat. Secara umum dari beberapa pernyataan responden didapatkan keterangan bahwa materi khutbah sering menyinggung perasaan, tidak terarah (sistematis), tidak ada kesimpulan, materi khutbah tidak sesuai dengan buku yang 
pernah mereka baca, materi khutbah yang berulang-ulang, materi khutbah sebaiknya ada yang lucu, materi khutbah sebaiknya sesuai dengan perkembangan zaman. Pernyataan-pernyataan itu merupakan alasan yang menyebabkan mereka tidak masuk ke dalam mesjid saat khutbah berlangsung. Selain itu, mereka juga memberikan keterangan bahwa khatib yang khutbah terlalu lama akan membosankan. Mereka mengusulkan agar khutbah hanya berlangsung 15 menit saja.

Merujuk kepada beberapa nash-nash mengenai khutbah yang disampaikan oleh Nabi Muhammad saw, maka didapatkan penjelasan bahwa inti materi khutbah semua bertema Iman dan Taqwa. Bahkan, inti utama dalam setiap khutbah yang disampaikan oleh Nabi saw adalah Taqwa. Menjadi kewajiban bagi setiap khatib dalam pembukaan khutbah berwasiat kepada seluruh kaum muslimin untuk menjaga dan meningkatkan taqwa kepada Allah swt. Dari sini dapat dikatakan bahwa materi utama khutbah jumat mesti bertemakan Taqwa dengan menghubungan situasi dan kondisi atau masalah dan peristiwa kontenporer yang berhubungan langsung dengan keimanan dan ketaqwaan. Selain materi atau tema khutbah, sebagian responden merasa tidak betah jika khutbah berlangsung relatif lama. Dari beberapa pernyataan mereka, nampak khutbah yang diinginkan adalah khutbah yang disampaikan relatif singkat.

\section{Fasilitas Mesjid}

Sebanyak 12 orang responden memberikan keterangan terkait dengan kebiasaan nongkrong di luar mesjid saat khutbah berlangsung. 5 responden memberi alasan bahwa untuk mendengar khutbah tidak mesti harus masuk dalam mesjid, karena di luar pun khutbah terdengar. 6 responden memberi alasan bahwa di dalam mesjid hawa panas karena tidak ada kipas angin/AC, mesjid sedang direnovasi, mic rusak, set sound sistem tidak baik sehingga di dalam mesjid tidak terdengar khutbah.

Berdasarkan beberapa keterangan tersebut, fasilitas sound sistem yang baik tidak menjamin jama'ah berada dalam mesjid saat khutbah berlangsung. Sebaliknya, ada jama'ah yang menjadikan alasan untuk berada di luar mesjid karena khutbah yang disampaikan oleh khatib juga terdengar. Selanjutnya, 
fasilitas mesjid seperti kipas angin, AC, Mic rusak, dan mesjid sedang dalam renovasi dapat dikatakan bersifat kasusistik. Dalam kata lain, tidak dapat dijadikan argumentasi kuat sebagai alasan berada di luar mesjid saat khutbah berlangsung, karena masalah seperti ini dapat diantisipasi oleh pengurus mesjid yang ada, tentu terkait dengan keadaan keuangan mesjid yang ada.

\section{Retorika Khatib}

Retorika atau gaya berbicara dalam menyampaikan suatu materi merupakan menjadi salah satu faktor yang menyebabkan aundence tertarik dan fokus terhadap apa yang disampaikan oleh key note speaker (khatib Jumat). Terkait dengan pembahasan dalam penelitian ini, 5 orang responden memberikan keterangan. Mereka mengatakan banyak khatib dalam berkhutbah suaranya hanya bikin mengantuk, penyampaian yang membosankan, kurang menarik, tidak enak didengar, dan tidak berkesan. Keterangan-keterangan ini yang menjadi alasan mereka tidak masuk mesjid saat khutbah. Jika mereka tahu khatib dapat melucu apalagi terkenal maka mereka akan masuk menyimak khutbah. Sebaliknya, jika mereka telah mengenal performance khatib dengan penilaian kurang memuaskan, mereka akan berada di luar mesjid.

Khatib sebagai key note speaker dalam khutbah memiliki tempat tertentu. Keberadaan khatib dalam memberikan khutbah di atas mimbar, menjadi mereka menjadi pusat perhatian jama'ah. Oleh sebab itu, jika khatib tidak mampu membuat dirinya menjadi pusat perhatian maka pada dasarnya pesan.

\section{Integritas Khatib}

Track record khatib dalam kehidupan sosial penting ditanyakan kepada responden. Hal ini cukup beralasan karena hampir setiap hari jama'ah melihat bahkan memiliki pengalaman bergaul atau berkomunikasi dengan seseorang yang sering menjadi khatib. Kewibawaan dan penyampaian nasehat-nasehat dalam khutbah sedikit banyaknya dipengaruhi oleh integritas kepribadian khatib. Integritas yang dimaksud di sini adalah perilaku seorang khatib di tengah-tengah masyarakat. Apabila prilaku khatib dinilai tidak baik oleh sebagian besar 
masyarakat, maka dapat diasumsikan perkataan khatib saat khutbah kurang muru'ah.

Terkait dengan integritas khatib dalam penelitian ini, ada 10 responden memberikan tanggapan, mengapa mereka sering berada di luar mesjid saat khutbah berlangsung. Ada dua responden memberikan keterangan sebagai berikut: 1. Tidak suka sama khatib, 2. Ucapan dan prilaku khatib ada yang tidak sesuai. Meskipun responden tidak memberikan keterangan lanjutan mengenai masalah integritas ini, akan tetapi kedua keterangan ini telah memberikan kesimpulan sementara bahwa integritas khatib penting. Sementara yang responden yang lain memberikan keterangan tidak terkait langsung dengan integritas khatib. Mereka hanya menuntut sesuatu dari dari khatib yang bersifat entertaiment;menghibur dalam artian dapat melucu/membuat lucu.

\section{Alasan-alasan Personalitas Jama'ah}

Ada 38 responden yang memberikan komentar dalam menjawab mengapa mereka lebih suka berada di luar mesjid saat khutbah berlangsung. Secara umum keterangan yang mereka berikan dapat dituliskan sebagai berikut: Di luar mesjid dapat merokok, cerita sama teman, jelang iqamat baru masuk, tidak bisa duduk lama, risih dianggap suci kalau masuk dengar khutbah, mengantuk di dalam karena khatib jarang ganti, kumpul dan cerita banyak hal dengan kawan-kawan, terlambat datang, diskusi pekerjaan dengan teman-teman, masuk pada khutbah ke dua, merasa bosan dalam mesjid, diajak teman ngobrol di luar, kalau masuk dalam mesjid ketiduran, main internet, disibukkan dengan pekerjaan akhirnya telat, tidak cerita dalam mesjid, di dalam mesjid kebanyakan orang tua, malu dianggap alim.

Konklusi yang dapat ditarik dari pernyataan-pernyataan personality tersebut dapat dikatakan bahwa inti persoalan kebiasaan nongkrong di luar mesjid saat khutbah berlangsung adalah faktor individu. Faktor-faktor itu berupa kekurangpahaman tentang urgensi mengikuti prosesi shalat jumat, latah dengan kebiasaan nongkrong, dan pengaruh teknologi informasi (akses internet kapan dan di mana saja).

\subsection{Solusi Mengurangi/Menghilangkan Kebiasaan Nongkrong}


Analisis 5 (lima) item pokok pertanyaan yang diajukan kepada responden (jama'ah jumat yang sering nongkrong) dan keterangan-keterangan yang bersifat personal, memberikan gambaran kompleks mengenai kebiasaan "anormatif" nongkrong tersebut. Fenomena anormatif tersebut pada intinya bersumber pada integritas personality seseorang sebagai muslim-mu'min. Integritas muslimmu'min yang ideal dalam persoalan ibadah seharusnya merujuk pada makna sami'na wa ata'na; kami mendengar dan kami taat serta menghadirkan dalam hati rasa raja'; penuh asa dan khauf; rasa takut. Memenuhi hati dengan sifat raja' dan khauf, pada dasarnya mengintegrasikan rasionalitas dan batiniyah seseorang mengenai adanya perintah dan larangan dalam Islam. Konsepsi sami'na wa ata 'na, raja' dan khauf, jika diproyeksikan mengenai urusan manusia di akhirat yang "nafsi-nafsi", dapat dikatakan cukup mencegah seorang muslim-mu'min tidak nongkrong di luar mesjid saat khutbah berlangsung. Namun konsepsi normatif tersebut berbeda dengan realitas. Fenomena anormatif kaum muslimin saat khutbah berlangsung itu seperti telah menjadi endemi yang massif di Sinjai.

Upaya penyebaran agama pada dasarnya merupakan satu bagian yang pasti ada dalam kehidupan umat beragama. Dalam ajaran agama Islam, hal ini disebut dengan dakwah, hal ini merupakan suatu kewajiban yang dibebankan oleh agama kepada setiap pemeluknya, setidaknya kewajiban berdakwah ini dilakukan kepada diri sendiri dan keluarga serta kerabat dekat. Dengan demikian, maka dakwah dalam agama Islam mempunyai basis personal yang cukup kuat dalam pribadi setiap pemeluknya (Barmawi Umary: 1987, 54). Dakwah adalah seruan atau ajakan kepada keinsafan, atau bisa jugadisebut sebagai upaya mengubah suatu situasi kepada situasi yang lebih baik dan sempurna, baik terhadap pribadi maupun masyarakat. Perwujudan dakwah bukan sekadar usaha peningkatan pemahaman keagamaan dalam tingkah laku dan pandangan hidup saja, tetapi menuju sasaran yang lebih luas lagi (Quraish Shihab: 1997, 194).

Oleh karena itu, perlu dilakukan pembaharuan sikap dan pencerahan mind set terhadap prosesi jumat. Pembaharuan dan pencerahan difokuskan pada masalah mengenai penanaman spiritalitas urgensi khutbah, formulasi materi khutbah yang informatif-efesien-efektif, fasilitias mesjid yang me-nyaman-kan 
jama'ah, retorika khatib yang komunikatif, membangun semangat integritas seorang khatib sebagai uswatun hasanah di tengah-tengah masyarakat. Secara filosofis, semangat amar ma'ruf nahi munkar dapat ditanamkan sehingga menjadi kesadaran utama bagi setiap muslim.

Pada dasarnya, khutbah khatib sebelum pelaksanaan shalat jumat merupakan nasehat kepada kaum muslimin. Nasehat agar senantiasa iman dan taqwa ditingkatkan dan diperbaharui. Iman dan taqwa yang tidak hanya berada pada tataran konsep/pengetahuan melainkan terwujud dalam realitas kehidupan sehari-hari. Khutbah sebagai nasehat akan memberikan dampak positif kepada umat Islam, hal ini ditegaskan oleh Allah dalam QS. An Nisaa':63,

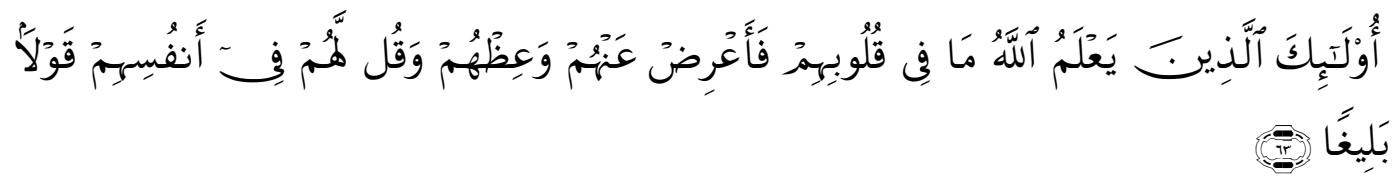

Terjemahan:

Mereka itu adalah orang-orang yang Allah mengetahui apa yang di dalam hati mereka. karena itu berpalinglah kamu dari mereka, dan berilah mereka pelajaran, dan Katakanlah kepada mereka Perkataan yang berbekas pada jiwa mereka.

Ayat di atas telah memberikan pedoman dan menjadi prinsip utama tablig yang disampaikan oleh Nabi Muhammad saw bersama para sahabat dan pengikutnya, sehingga Islam dengan cepat berkembang dengan baik ke seluruh penjuru dunia (Ulil Amri Syafri: 2007, 16). Prinsip tablig itu diakui oleh sebagian penulis di Barat, di antaranya Lippinan yang mengatakan: “ Islam digerakkan bukan dengan pedang tapi dengan tutur kata yang bergairah dan keteladanan, akhirnya dapat mencapai wilayah-wilayah di Asia, Afrika, Eropa dan Amerika tanpa mengenal kekuasaan pusat missionaris (Husein: 2000,2).

\section{Kesimpulan}

1. Shalat Jumat dan khutbah merupakan satu rangkaian yang tidak terpisahkan dalam prosesi ibadah di hari jumat. Banyak dalil al-Qur'an maupun hadis shahih yang dapat menjadi landasan mengenai fardhunya khutbah. Empat mazhab fiqhi yakni Hanafiyah, Malikiyah, Syafi'iyah, dan Hambaliyah telah memberikan rumusan rukun pelaksanaan prosesi shalat jumat. Pembahasan 
khusus mengenai prosesi jumat menunjukkan urgensi pelaksanaannya. Pesan inti setiap khutbah di hari jumat kepada jama'ah adalah taqwa. Selain pesan inti tersebut, khutbah juga berfungsi sebagai media informasi tentang masalah-masalah keagamaan. Demikian pula pelaksanaan shalat jumat di mesjid merupakan wadah berkumpul dan silaturrahim umat Islam sekali dalam seahad.

2. Meskipun dalam kajian teologis berikut dalil-dalil tentang pelaksanaan dan mengikuti khutbah hukumnya wajib namun realitas jama'ah jumat sering nongkrong di luar mesjid saat khutbah berlangsung. Ada beberapa faktor yang menjadi alasannya antara lain: Materi yang monoton, penyampaian yang kurang enak didengar, integritas khatib sering dipertanyakan, fasilitas mesjid yang tidak cukup. Selain itu, terdapat alasan-alasan personal, seperti: Sakit-tidak dapat duduk lama, mengantuk, terlambat, cerita di luar mesjid, ngenet, dan diajak teman.

3. Menyikapi realitas kebiasaan nongkrong di luar mesjid saat khutbah berlangsung sesungguhnya dapat dikurangi jika tidak berlebihan dikatakan dapat dihilangkan. Adapun caranya adalah menyiapkan materi yang aktual tanpa keluar dari pesan inti dari khutbah yaitu Iman dan takwa, waktu penyampaian harus efektif yakni antara 15-20 menit, integritas khatib dalam artian kemampuan intelektual dan akhlak mesti terintegrasi, dan menggunaan media penyampaian khutbah misalnya menggunakan LCD. Meskipun yang disebutkan terakhir berimplikasi munculnya kontroversi pendapat dalam perspektif hukum, namun hal dapat diwacanakan kepada para ulama. Selain itu, setiap mesjid dapat membuat website atau grup-grup medsos dengan menggunakan aplikasi-aplikasi tertentu sebagai media berbagi informasi, interaksi dunia maya sebagai wujud sisi lain menjalin silaturrahim. 


\section{DAFTAR PUSTAKA}

Abdullah ibn Muhammad ibn Abu Syaibah al-Kufy, Abu Bakar. Mushannif Ibnu Abi Syaibah, (Saudi: Dar al-Salafiyah, tt), Hadits no. 5176, jilid. 2.

Ad Daraquthni, Imam. Sunan Ad Daraquthni, dengan hasyiyah kitab At Ta'liq Al Mughni 'Ala Ad Daraquthni, karya Abu Ath Thayyib Muhamamd Al Abadi, Cetakan Ketiga, Tahun1413 H, Alam Al Kutub, Bairut,

Ahmad ibn Hazam al-Zhohiri, Ali ibn. Jawami“ al-Sirah wa Khamsa Rasail Ukhra libni Hazam, (Mesir: Dar al-Ma'arif,

Al 'Asqalani, Ibnu Hajar. Talkhish Al Habir Fi Takhrij Ahadits Ar Rafi'i Al Kabir. Cetakan Pertama, Tahun 1416, Muassasah Al Qurthubah dan Makbatabh Al Makiyah, Makkah, KSA

Al Baihaqi. Sunan Al Kubra, ditahqiq oleh Muhammad Abdulqadir 'Atha, Cetakan Pertama, Tahun 1414 H, Dar Al Kutub Al Ilmiyah, Bairut

al- Jaziri, Abdurrahman. .al - Fiqh 'ala Mad à hib al-Arba'ah,. Beirut Dar al Fikr . 1987

al-Suyuthi, Jalaluddin. Jami ‘ al-Ahadits, (Maktabahal-Syamilah), jilid. 25,

al-Zuhaili, Wahbah. al-Tafsir al-Munir fi al-Aqidah wa al-Syariah wa al-Manhaj, (Damaskus: Dar al-Fikr al-Mu'ashir, 1418 H), jilid. 28.

Amri Syafri, Ulil et.al., Da'wah, Mencermati Peluang dan Problematikanya(STID Mohammad Natsir Press; Jakarta, 2007

Arfan, Abbas. Fiqih Ibadah Peraktis, malang: Uin-Maliki Press

As-Suyuti, Imam. Khususiyat Al-Yaum Al-Jum'ah, Damaskus: Daar al-Fikr 1964 .

Connolly, Peter. Aneka Pendekatan Studi Agama, (Cet. I; LKiS:Yogyakarta, 2001.

Dawud, Abu. Sunan Abu Daud, Kitab Ash Shalat, Bab Al Jum'at Lil Mamluk Wal Mar'ah, no. 1067

Habib, M. Syafaat. Pedoman Dakwah dan Khutbah (Cet. 1; Widjaya: Jakarta, 1992.

Harum, Rahmatullah. Sinjai dari Masa ke Masa (ditulis pada tahun 2006, tidak diterbitkan

Hasan, Ikbal. Pokok-pokok Materi Penelitian dan Aplikasinya (Cet. I; Bogor: Galia Indonesia,

Husein, Mochtar. Tablig Yang Baik (Cet. I; Dar Al-Hukama: Makassar, 2000.

Ibn Jarir al-Thabari, Muhammad. al-Jami ‘ al-BayanFi Takwil al-Quran, (Bairut: Muassasah al-Risalah,2000), Jilid. 23.

Kartodirdjo, Sartono. Pendekatan Ilmu Sosial dalam Metodologi Sejarah (Cet.II; Gramedia Pustaka Utama: Jakarta, 1993. 
Kemenag RI, Tafsir Al Qur'an dan Terjemahan

M. Rifa'i, et al. terj. Kifayatul Akhyar, Semarang: Toha Putra , 1993

Muhammad Al Mubarakfuri, Syaikh Ubaidilah bin. Mir'atu Al Mafatih Syarh Al Misykat Al Mashabih, (Cet. IV, Tahun 1415 H, Idaratul Buhuts Al Islamiyah Wad Dakwah Wal Ifta' di Jami'at Al Salafiyah Banarest, India

Muhammad Syamsulhaq Adzim, Abu Thayyib. Aunul Ma'bud Syarh Sunan Abi Dawud, Abadi, tanpa tahun, Dar Al Kutub Al Ilmiyah,

Nasib ar-Rifaii, Muhammad. Ringkasan Tafsir Ibnu Katsir, trj. Syihabuddin, (Jakarta: Gema Insani Press, 2000.

Nawawi, Imam. Majmu' Syarh Al Muhadzdzab, di Tahqiq oleh Muhammad Najib Al Muthi'i, Cetakan Tahun 1425 H , Dar Ihya At Turats Al Islami.

Pemerintah Daerah Kabupaten Sinjai, Company Profil Kabupaten Sinjai (Cet. I; t.tp: Badan komunikasi dan Informatika Kabupaten Sinjai, 2008.

Rifa'I, Moh. Fiqih Islam Lengkap, (Semarang: PT. Karya Toha Putra, 1978.

Rusyid, Ibnu. Bidjatul Mudjatahid. Jilid III (Jakarta: Bulan Bintang, 1969

Shadily, Hassan. Sosiologi untuk Masyarakat Indonesia (Cet IX; Bina Aksara: Jakarta, 1983.

Shihab, Quraish. Membumikan Al-Qur'an (Cet. I; Mizan; Bandung:,1997

Sugiyono, Metode Penelitian Pendidikan-Pendekatan Kuantitatif, kualitatif, dan $R \& D$ (Cet. XI; Bandung, 2010.

Suyuti, Achmad. Jadilah Khatib Yang Kreatif dan Simpatik (Cet. I; Pustaka Amani: Jakarta, 1995

Syaikh Al Albani, Irwa' Al Ghalil Fi Takhrij Ahadits Manar As Sabil, , Cetakan Kedua, Tahun 1405 H, Al Maktab Al Islami

Umary, Barmawi. Azas-azas Ilmu Dakwah (Cet. I; Ramadhany: Solo, 1987 